Gut, 1973, 14, 213-214

\title{
Primary biliary cirrhosis in twin sisters
}

\author{
M. R. CHOHAN \\ From Essex County Hospital, Colchester
}

SUMMARY Primary biliary cirrhosis in twin sisters is described. The incidence of this rare disease in young women is high but whether there is any genetic or familial association in twin sisters is not known.

Primary biliary cirrhosis, which mainly occurs in women, was first described by Addison and Gull in 1851 and by Hanot in 1892. It has recently been reassessed by Ahrens, Payne, Kunkel, Eisenmenger, and Blondheim (1950) and by Sherlock (1969).

It is characterized by itching, obstructive jaundice, and an increase in lipids in serum. Recognizable disease may be present for as long as five years before cirrhosis develops. The liver is enlarged and green, and its capsular surface is smooth, at least in the early stages. Microscopically the essential early lesion is a heavy inflammatory infiltration in the portal tracts, lymphocytes, and plasma cells. This reaction may be so marked that granulomas may form, identical with sarcoidosis (Kuhn, 1963). At the final stages in primary biliary cirrhosis difficulty is experienced in deciding whether the original lesion was in fact primary biliary cirrhosis or one following infection.

The cause of primary biliary cirrhosis is not known but it is associated with considerable immunological disturbance both specific and non-specific. The serum shows an increase in $\gamma \mathrm{M}$ immunoglobulin. Antimitochondrial antibodies are positive in $98 \%$ of cases. The coincidence of twin sisters developing primary biliary cirrhosis and also in two brothers described by $\mathrm{Da}$ Silva and De Brito in 1966 and by Kuhn in 1963 suggests that there may be a genetic or familiar factor, although the evidence is far from conclusive.

\section{Case Reports}

CASE 1

Mrs J.P., aged 29, was first seen in July 1970. She was jaundiced during her pregnancy but the baby was delivered at home with no complications. She also noticed considerable itching of the skin and the urine

Received for publication 21 December 1972. had been dark and the stools pale about 10 months before her admission to hospital. Her appetite was also poor. She had jaundice at the age of 5 at the same time as her twin sister. She had no recurrence.

On examination she was abviously jaundiced but there was no lymphadenopathy, no finger clubbing, no spider naevi, and no palmar erythema. The liver was enlarged 3 fingerbreadths and was smooth with an irregular edge. There was no splenomegaly and no ascites or ankle oedema.

Investigations gave total bilirubin $6.0 \mathrm{mg} / 100 \mu \mathrm{l}$, alkaline phosphatase $96 \mathrm{KA}$ units, thymol turbidity 6 units, zinc sulphate turbidity 8 units; haemoglobin $12 \mathrm{~g} / 100 \mathrm{ml}$, ESR $82 \mathrm{~mm} / \mathrm{hr}$, reticulocytes $1 \%$, blood group A positive; serum cholesterol $410 \mathrm{mg} / 100 \mu \mathrm{l}$, SGOT 39 units, SGPT 67 units. No LE cells were seen, and antinuclear factor was negative. Mitochondrial (fluorescent CFT) was positive $++1 / 265$, antibodies to smooth muscle $1 / 11$.

Only a small portion of liver was available on biopsy. The portal tracts were obviously widened and heavily infiltrated by inflammatory cells, and piecemeal necrosis was present at the periphery of the lobules. Some atypical bile duct proliferation was noted. A mild degree of bile stasis was present in both periportal and centrilobular areas. There was no increase in iron.

The patient was treated with azathioprine (Imuran).

CASE 2

Mrs G.M., aged 29 (twin sister), was noticed to be jaundiced when she was admitted in July 1972, after excessive vaginal bleeding following a dilatation and curettage for cervicitis. She was given a blood transfusion, but was noticed to be jaundiced before the transfusion. Her appetite had been poor since October 1971 and she had been getting pains in the joints and had a raised antistreptolysin $O$ titre $(\mu / \mathrm{ml}) 625$. She was treated for subacute rheumatism and was given penicillin $\mathrm{V}$ and aspirin. She also had 
had jaundice at the age of 5 when her twin sister also had jaundice.

On examination she was jaundiced. There was no clubbing, no lymphadenopathy. She had scratch marks over the dorsum of the hands and ankles due to itching; the liver was palpable to two fingerbreadths, the surface firm and smooth. The spleen was not palpable. There was no ascites or ankle oedema. The heart sounds were normal, and she had a soft systolic murmur over the apex.

Investigations gave total bilirubin $5 \cdot 1 \mathrm{mg} / 100 \mathrm{ml}$, conjugated positive; alkaline phosphatase $112.5 \mathrm{KA}$ units; haemoglobin 9.0 g/dl. The ESR was 107 $\mathrm{mm} / \mathrm{hr}$. She was blood group A, positive. Serum cholesterol was $381 \mathrm{mg} / 100 \mathrm{ml}$, serum iron 56 $\mu \mathrm{g} / 100 \mathrm{ml}$, folate $4.4 \mathrm{ng} / 100 \mathrm{ml}$, serum vitamin $B_{12}$ $540 \mathrm{pg} / \mathrm{ml}$. The test for LE cells was negative as was that for antinuclear factor. Plasma proteins totalled $6.5 \mathrm{~g} / 100 \mathrm{ml}$ (albumin $2.6 \mathrm{~g} / 100 \mathrm{ml}$, globulin $3.9 \mathrm{~g} / 100 \mathrm{ml}$ ). IgA was $280 \mathrm{mg} / \mathrm{dl}$, IgG 1100 $\mathrm{mg} / \mathrm{dl}, \mathrm{IgM} 200 \mathrm{mg} / \mathrm{dl}$. Mitochondrial antibodies were positive on immunofluorescence. Complementfixation titre was $1 / 256$. Hepatitis-associated antigen was not found, nor was antibody to it detected.

Liver biopsy showed a well marked biliary cirrhosis with dense infiltration, mainly of lymphocytes and plasma cells, in the portal tracts not associated with any obvious biliary retention or reduplication of bile ducts. Fibrous tissue extended from the portal tracts or to the capsule and was accompanied by cellular infiltrations. In addition occasional giant cell granulomata were found, some of these in close association with bile ducts but some found in the liver parenchyma.

She was treated with cholecystamine (Questran) for itching and also started on azathioprine and prednisone.

I wish to thank Dr A. B. Pollard, consultant physician of Essex County Hospital, Colchester, and Dr A. E. Dormer, consultant physician, Connaught Hospital, London, for their permission to report the cases.

\section{References}

Addison, T., and Gull, W. (1851). On a certain affection of the skin. Vitiligoidea and plana and tuberosa. Guys Hosp. Rep., 2nd ser., 7 (2), 265-276.

Ahrens, E.'H., Jr., Payne, M. A., Kunkel, H. G., Eisenmenger, W.J., and Blondheim, S. H. (1950). Primary biliary cirrhosis. Medicine (Baltimore), 29, 299-364.

Da Silva, L. C., and De Brito, T. (1966). Benign recurrent intrahepatic cholestasis in two brothers. Ann. intern. Med., 65, 330-341.

Hanot, V. (1876). Etude sur une Forme de Cirrhose Hypertrophique du Foie (Cirrhose Hypertrophique avec Ictere Chronique). Balliere, Paris.

Kuhn, H. A. (1963). Intrahepatic cholestasis in two brothers. Germ. Medicine Mth., 8, 185-188.

Sherlock, S. (1959). Primary biliary cirrhosis. (Chronic intrahepatic obstructive jaundice.) Gastroenterology, 37, 574-589.

Sherlock, S. (1969). Diseases of Liver and Biliary system, 4th ed., pp. 305-312. Blackwell, Oxford. 